\title{
New Paradigm in the Observation of Pigmentary Epithelium of the Retina. (Optical Digital Biopsy)
}

\author{
Zarate Jorge Oscar* \\ Maimonides University and Department of Pathology, Argentina
}

Submission: August 20, 2018; Published: September 21, 2018

*Corresponding author: Zarate Jorge Oscar, Chairman. Digital Pathological Laboratory and Ophtalmological Visual and Sciences, Maimonides University and Department of Pathology. Buenos Aires University. Argentina, Email: zjorgeoscar@yahoo.com.ar

\section{Introduction}

There is a new paradigm in morphological imageny: it emerges from the intersection of physics, biology and informatics: information as the primary foundation of the universe we perceive and perhaps matter and energy as its representation or unfolding.

This paper summarizes our activity in the laboratory of Digital Pathology of the Maimonides University and the Laboratory of Ophthalmological Investigations and Visual Sciences (LIOCIV) at the University of Buenos Aires (UBA), Department of Pathology, Center for Experimental and Applied Pathology.

In its most basic constitution is made of tiny subatomic particles; These particles are equivalent to discrete packets of energy that are constantly transmitted in the vacuum-quantums. This concept is related to a universe of matter and / or energy (theory of relativity).

It is the fusion of physics with computer theory and genetics, a new understanding of what is the fundamental substrate of the universe: information. In this work, we present some of the physical morphological results obtained from the sequencing of images with digital optical biopsy [1], using pixelometric and pixelographic criteria [2-4].

The cellular and tissue images, although they have a known pattern, show the difference of a pure, active image, captured by a tomography (OCT), or optical coherence tomography. Information generates "every being-every particle, every force field, even the time-space continuum." This is another way of probing the paradox of the observer: the result of an experiment is affected, even determined, when it is observed. Not only is the observer watching, he is asking questions and utterances that ultimately must be expressed as discrete bits. "What we call reality," Wheeler timidly wrote, "arises in the last analysis of posing yes or no questions." "All physical thing in order to transform the numeric information that a pixel stores in a color, we must know, in addition to the depth and brightness of the color (the size in bits of the pixel), the color model we are using. For example, the RGB (Red-Green-Blue) color model allows you to create a color by making two basic colors and one secondary color: red and blue (primary) and green (secondary). In this way, depending on the amount of each of them that we use we will see one result or another. For example, the violet color is obtained by mixing red and blue.

The different shades of violet are obtained by varying the proportion in which both components are involved. In the RGB model, 8 bits are often used to represent the proportion of each of the three primary components. Thus, when one of the components is 0 , it means that it does not intervene in the mix and when it is worth $255(28-1)$ it means that it intervenes contributing the maximum of that tone. The majority of the devices that are used with a Computer (monitor, scanner, ...) use the RGB model.

A pixel reaches 8 bits ( 28 colors), 24 bits ( 224 colors) or 48 bits (240 colors), this last value of precision is only obtained with scanners or cameras of high range (that use format raw or tiff, not in Jpg). According to Oxford University physicist Vlatko Vedral, Eduardo Punset, the Universe itself would not be composed of matter or energy but of information.

The smallest scale in the universe-the one governed by the laws of quantum physics-seems a challenge to common sense. Subatomic objects (pixel representation) can be in more than one place at a time, two particles at opposite ends of a galaxy can share information instantly, and the mere fact of observing a quantum phenomenon can radically change it [5-7].

However, the possibility of storing their own information, a unit, which is the pixel, makes it more accurate, dynamic and reliable. Quantum physics is the physics of the possibilities of change, management of unified fields of the four forces: gravity, electromagnetism and the strong and weak force of the atomic nucleus.

Einstein suggested in his theories, the existence of a field holding space-time transformations and mass - energy. This field is the pixel. In the different photos that we show, can be seen digital secuentiation of the retina tissue, detection technique based in sequencing images, obtained in our Digital Laboratory (Maimonides University) (Figure 1-4). 


\section{JOJ Ophthalmology}

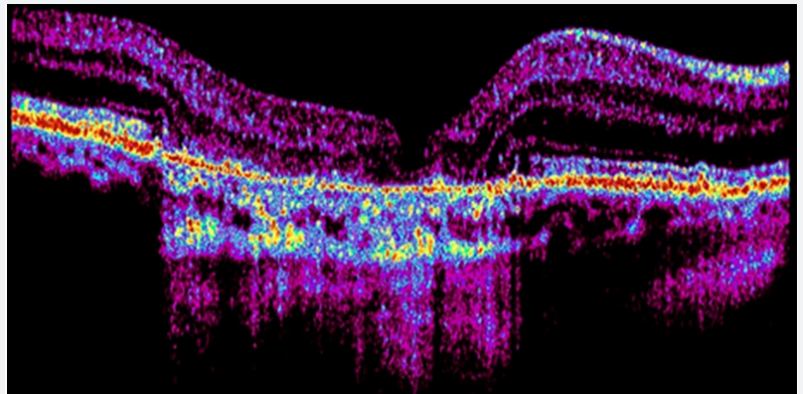

Figure 1: Panoramic view of digital optical bopsy (of OCT).

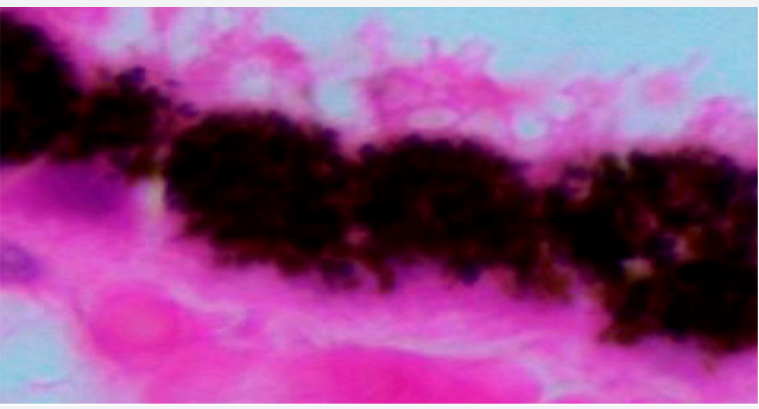

Figure 2: Pigmentaru epithelium.Phisical aspects.

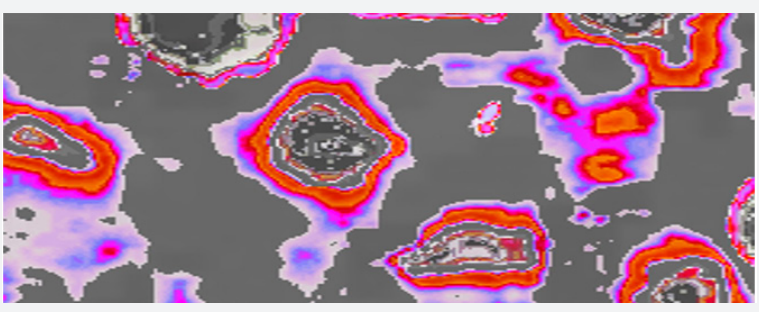

Figure 3: Pigmentary cells of pigmentary epithelium.

Phisical aspects. Taken from the OCT subsequent sequencing of imagesnes

Figure 4: Panoramic Image pixelographic of retina.

\section{References}

1 Zarate J0, Pelayes D, Singh A (2012) Optical Digital Biopsy. A new method of tissue and cell identification with ophthalmic applications. Patología 50(3): 179-181.

2 Zárate JO (2013) Optical Digital Biopsy. Brush strokes and pixels in the wonderful Latinamerican iconography. Patología 51(3): 206-209.

3 Zárate JO (2014) Digital optical biopsy. Possible extension to no other ophthalmic tissue. Patología Rev Latinoam 52: 246-247.

4 Zarate J0 (2014) The pixelometría. New non-Euclidian geometry, biological importance. Patologia 2014 (Mex)
5 Zárate JO et al. (2015) Optical Digital Biopsy: Uveal Choroidal Melanoma: Case Report and Update of Technology. Open Science Journal of Clinical Medicine 3(2): 59-63.

6 Zarate JO, Pelayes D, Folgar M (2018) La pixelometría aplicada al aislamiento de imágenes, en patología de la retina, con especial referencia al epitelio pigmentario. Highlights of Vitreoretina 11(1).

7 Zarate JO, Folgar M, Pelayes D (2016) Digital Optical Biopsy. Scores of pixels for processing images of optical coherence tomography to microscopy. Patología Rev Latinoam 54(4): 206-208. 
This work is licensed under Creative Commons Attribution 4.0 License DOI: 10.19080/JOJO.2018.07.555707
- Quality Editorial service

- Swift Peer Review

- Reprints availability

- E-prints Service

- Manuscript Podcast for convenient understanding

- Global attainment for your research

- Manuscript accessibility in different formats

( Pdf, E-pub, Full Text, Audio)

- Unceasing customer service

Track the below URL for one-step submission https://juniperpublishers.com/online-submission.php 